\title{
ELECTRICAL ENERGY CONSERVATION AND AUDIT AT R. C. PATEL POLYTECHNIC- A CASE STUDY
}

\author{
Prof. V.P. Mahajan \\ HOD in Electrical Engg. Department \\ R.C. Patel Polytechnic Shirpur.
}

\author{
Prof. Ms.H.A. Badgujar \\ Lecturer in Electrical Engg. Department \\ R.C. Patel Polytechnic Shirpur.
}

\begin{abstract}
In present scenario the need for energy is always increasing nowadays. As energy demand keeps on rising more of it in specified form needs to be generated. Because of rise in population, industrialization, change in life style, there is steep rise in energy demand. If rate of consumption of energy increases similarly then no sources will be left over for next generation. Hence energy conservation is needed as it reduces energy demand, energy cost. An energy audit is a study of a process to determine how and where electrical energy is used and also to identify methods for conserving energy. During the energy audit, a complete survey of power consumption in R. C. Patel Polytechnic College was carried out. Audit was conducted for lighting loads, fans, computers, air conditioners, single phase/three phase water pump, laboratory equipment and their power consumption pattern was determined. So this paper represents the energy consumption in educational institute as well as energy conservation techniques are recommended for minimizing the power consumption in the college.
\end{abstract}

Keywords:- Energy Audit, Energy Conservation, Recommendations, Institute.

\section{INTRODUCTION}

Electricity plays important role and serves as the essential ingredient for the industrial and all-round development of any country. As the natural resources are limited and energy uses are increasing day by day so it is very necessary to save natural resources by reducing energy consumption which can be achieved by using energy efficient equipment's and also by making people aware about energy conservation. BEE organization stated the objectives and management of energy on their site. The primary objective of Energy Audit is to determine ways to reduce energy consumption per unit of product output or to lower operating costs. Energy Audit provides a standard for managing energy in the organization and also provides the basis for planning a more effective use of energy throughout the organization [1]. As per the Energy Conservation Act, 2001, Energy Audit is defined as "the verification, monitoring and analysis of use of energy including submission of technical report containing recommendations for improving energy efficiency with cost benefit analysis and an action plan to reduce energy consumption".

Execution of recommended measures can help consumers to achieve significant reduction in their energy consumption levels [2]. Energy audit analysis in general order involves: 1. Analysis of the energy consumable systems and the utility bills

2. Survey about the condition of the system

3 . Understanding the need of the consumer

4. Evaluating the possible energy conservation measures and the energy savings potential.

Educational institutions require energy auditing process due to expansion. In such institutions, the major electrical energy utilizations are normally lighting loads and air conditioning systems. Dr. P. S. Aithal [2015] stated in his paper study on electric system and the power consumption. The electrical energy consumption by lighting loads and air conditioners or fans are approximately $20 \%$ and $50 \%$ respectively. [3] Also energy conservation awareness can be created in the institute by placing the slogans in campus of institute. In this paper equipment wise analysis has been performed in order to identify the electrical equipment's within same application area, which consume more power as compared to others. During equipment wise analysis of the overall campus, the equipment's with power consumption less than $1 \%$ of total power consumption of the campus were ignored so as to make the analysis results simple and easy to observe.

\section{i. Problem formulation}

The total electricity bill for the previous year i.e. 2019-20 is Rs. 8, 08589 and power consumption is near about 59202 $\mathrm{kWh}$ in complete year. Afterwards the institute is planning to increase the floors of building as well as some labs of different departments are being installed in next year. So obviously the power consumption of institute will be increase. Therefore in order to manage power requirement there is an entire necessity to save the energy consumption. In order to achieve the required savings in power, different steps need to be taken. The details of all the components and factors involved need to be examine. 


\section{International Journal of Engineering Applied Sciences and Technology, 2020 \\ Vol. 4, Issue 12, ISSN No. 2455-2143, Pages 135-139 \\ Published Online April 2020 in IJEAST (http://www.ijeast.com)}

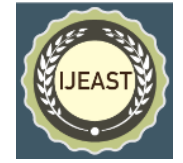

\section{ii. Objectives of this paper}

The main objective of this paper is to examine the facts of energy consumptions of complete campus by auditing process. Audit is carried out by considering all the load equipment's that are connected in campus. The another purpose is to identify maximum energy consumption equipment's in campus and find out the energy conservation opportunities. The target is to achieve savings in the energy consumption to the extent of $20 \%$ to $40 \%$. The audit was also aimed to learn about the practical problems and difficulties in carrying out energy audits.

\section{METHODOLOGY}

\section{i) Energy audit process}

Energy audit needs to be flexible based on the type of organization. Energy Audit to be performed depends on:

- Function and type of industry/Institute

- Depth to which final audit is needed, and

- Potential and magnitude of cost reduction desired

Thus, energy audit can be classified into the following two types.

\section{a) Preliminary audit}

b) Detailed audit

The preliminary audit alternatively called as a walkthrough audit. It is the simplest and quickest type of audit. It involves minimal interviews with site-operating personnel, a brief review of facility utility bills and other operating data, and a walk-through of the facility to become familiar with the building operation and to identify any glaring areas of energy waste or inefficiency. Typically, only major problem areas will be covered during this type of audit.

Detailed energy audit, also known as comprehensive energy audit. This type of audit offers the most accurate estimate of energy savings and cost. It considers the interactive effects of all projects, accounts for the energy use of all major equipment, and includes detailed energy cost saving calculations and project cost. The duration required for this type of audit is long nearly eight to 10 weeks.

Detailed energy auditing is carried out in three phases: Phase I, II and III.

Phase I - Pre Audit Phase

Phase II - Audit Phase

Phase III - Post Audit Phase

Phase- I Pre audit phase is an initial study of the institution as the planning of detailed auditing. This visit may take one or two days and gives the Energy Auditor or Engineer an opportunity to meet the personnel concerned, to familiarize him with the site and to assess the procedures necessary to carry out the energy audit. Phase II- Auditing phase varies depending on the nature and difficulty of the site, a full audit can take from numerous weeks to several months to complete. Detailed audit is done to establish and investigate the energy taken as input, output and losses. Frequently, checking of plant operations is carried out over unlimited periods of time may be at nights, weekends as well as during normal daytime operating hours, to ensure that nothing is ignored. Phase III - Post audit phase taking the detailed analysis of the action plan and scheduling the implementation process.

In our institute we have conducted preliminary audit by considering connected load. The process of conducting audit was as shown in fig. below.

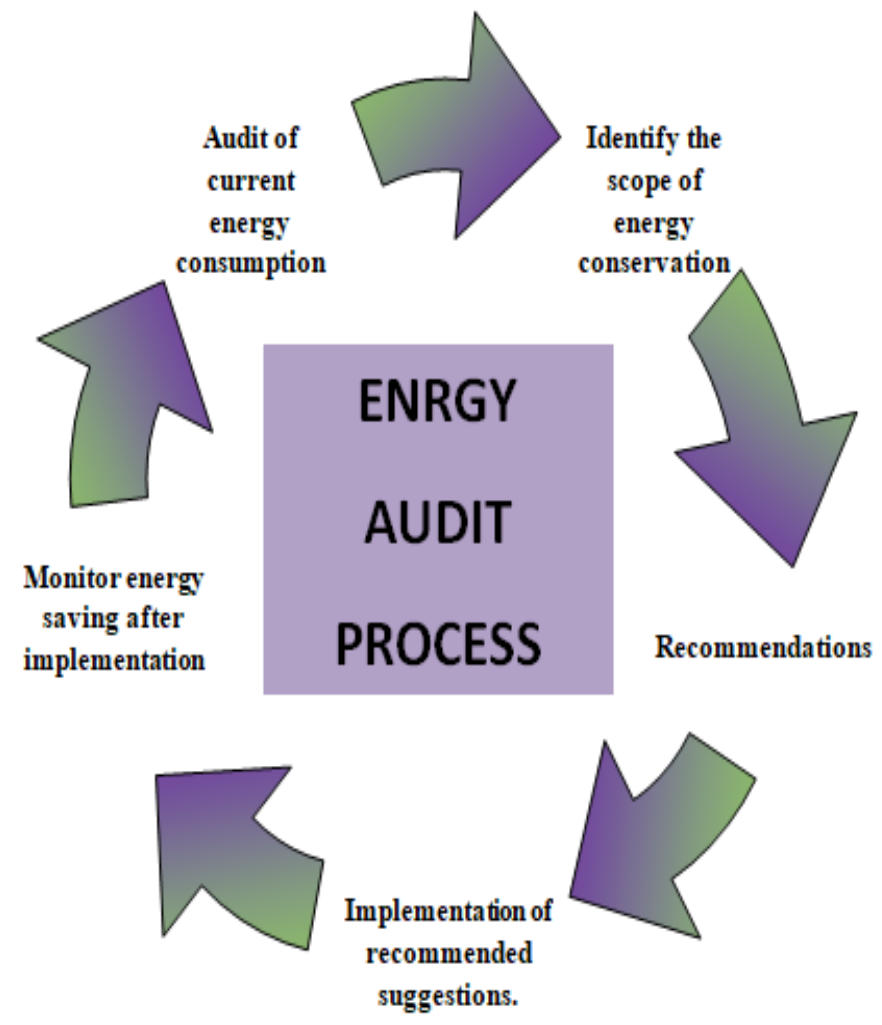

Fig.1. Energy Audit Process.

\section{ii) Equipment used for audit.}

To carry out the detailed audit we require various instruments for measurement of illumination, voltage, current...etc. The requirement for an energy audit such as identification and quantification of energy necessitates measurements; these measurements require the use of instruments. These instruments must be portable, durable, easy to operate and relatively inexpensive. The parameters generally Monitored during energy audit may include the following:

Basic Electrical Parameters in AC \& DC systems - Voltage, Current, Power factor, Active power, apparent power (demand), Reactive power, Energy consumption, Frequency, Harmonics, and some of the instruments are used like Lux Meter, Clamp on Meter, Energy Meter, Thermal Imager, Power Quality Analyser etc. 


\section{International Journal of Engineering Applied Sciences and Technology, 2020 \\ Vol. 4, Issue 12, ISSN No. 2455-2143, Pages 135-139 \\ Published Online April 2020 in IJEAST (http://www.ijeast.com)}

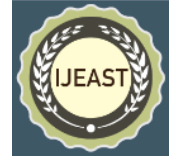

iii)

Energy scenario-

Institute started in the year 2016 and has taken the Electricity Installation of $80 \mathrm{KW}$ Power from Maharashtra State Electricity Board. The monthly recorded peak demand for the year 2019 is given in table and figure.

\begin{tabular}{|c|l|c|}
\hline Sr. No. & \multicolumn{1}{|c|}{ Month } & No. of Units \\
\hline 1 & January-2019 & 3,498 \\
\hline 2 & February-2019 & 4,153 \\
\hline 3 & March-2019 & 5,665 \\
\hline 4 & April-2019 & 4,508 \\
\hline 5 & May-2019 & 4,536 \\
\hline 6 & Jun-2019 & 4,661 \\
\hline 7 & July-2019 & 5,679 \\
\hline 8 & August-2019 & 5,796 \\
\hline 9 & September-2019 & 6,313 \\
\hline 10 & October-2019 & 6,120 \\
\hline 11 & November-2019 & 4,478 \\
\hline 12 & December-2019 & 3,795 \\
\hline & $\quad$ Total & $\mathbf{5 9 , 2 0 2}$ \\
\hline
\end{tabular}

Table: 1- Energy Consumption Details (January 2019 to December 2019)

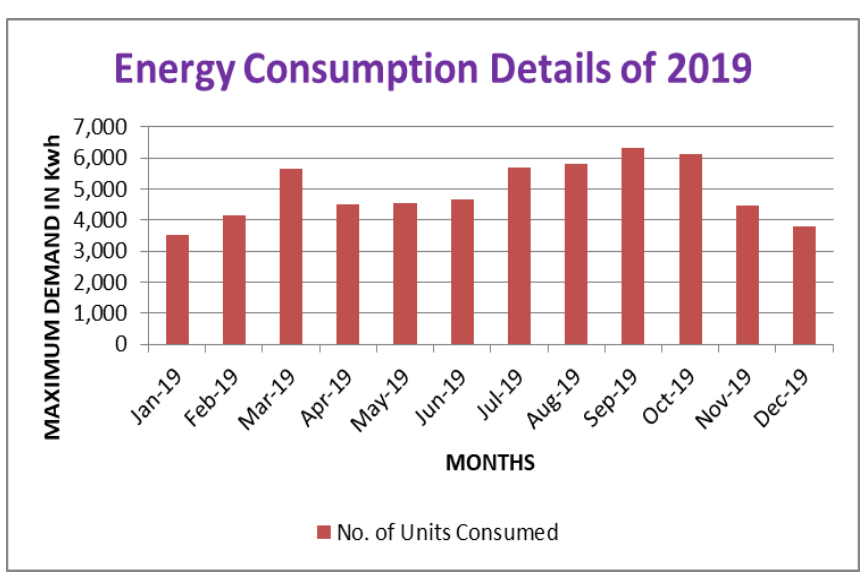

Figure 2. Recorded monthly peak demands during year 2019

\section{ELECTRICAL ENERGY AUDIT CALCULATIONS AND RESULTS}

Various electrical and electronics devices are used in institute which are continuously in working condition. Every electrical device which are connected in college campus are not energy saving devices. These devices can be changed by electrical efficient appliances. Some appliances are of having high wattage, so the electrical consumption is high in college campus. An educational institutes uses various electrical and electronics equipment's for office as well as for teaching purpose.

* Below table shows energy consumption in May month

Table.-2- Power consumption of equipment's used per day in institute.

\begin{tabular}{|c|c|c|c|c|c|c|c|c|c|}
\hline $\begin{array}{l}\text { Sr } \\
\dot{\mathbf{N}} \\
\text { o. }\end{array}$ & $\begin{array}{c}\text { Name / Room } \\
\text { No. }\end{array}$ & Е & 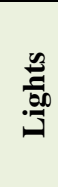 & $\frac{\mathscr{E}}{E}$ & 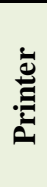 & 离 & ن & & 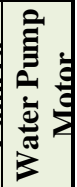 \\
\hline 1 & Office & 5 & 27 & - & 2 & 6 & - & 1 & - \\
\hline 2 & $\begin{array}{l}\text { Principal } \\
\text { Cabin }\end{array}$ & 1 & 4 & & 1 & 1 & 1 & - & - \\
\hline 3 & $\begin{array}{l}\text { APS Dept. } \\
\text { Labs }\end{array}$ & 10 & 12 & 2 & 1 & 27 & 1 & - & - \\
\hline 4 & EE Dept. Labs & 13 & 6 & 4 & 1 & 1 & - & - & - \\
\hline 5 & $\begin{array}{l}\text { E\&TC Dept. } \\
\text { labs (4) }\end{array}$ & 15 & - & 2 & - & 16 & - & - & - \\
\hline 6 & $\begin{array}{l}\text { Mech. Dept. } \\
\text { Labs }\end{array}$ & 9 & 2 & 8 & - & 1 & - & - & - \\
\hline 7 & $\begin{array}{l}\text { Civil Dept. } \\
\text { Labs }\end{array}$ & 11 & 6 & 2 & - & 2 & - & - & - \\
\hline 8 & $\begin{array}{l}\text { Computer } \\
\text { Dept. Labs }\end{array}$ & 10 & 18 & - & 1 & 97 & 2 & 3 & - \\
\hline 9 & Drawing Hall & 4 & - & 2 & - & - & - & - & - \\
\hline 10 & $\begin{array}{l}\text { Conference } \\
\text { Room }\end{array}$ & 1 & 1 & - & - & - & - & - & - \\
\hline 11 & Library & 11 & - & 6 & - & 5 & - & - & - \\
\hline 12 & $\begin{array}{l}\text { Faculty } \\
\text { Seating }\end{array}$ & 13 & 10 & - & - & 7 & - & - & - \\
\hline 13 & $\begin{array}{l}\text { Exam Control } \\
\text { Room }\end{array}$ & 3 & - & - & - & - & - & 1 & - \\
\hline 14 & $\begin{array}{l}\text { Class Rooms } \\
(8)\end{array}$ & 42 & 30 & - & - & - & - & - & - \\
\hline 15 & $\begin{array}{l}\text { Placement } \\
\text { Cell }\end{array}$ & 1 & - & 1 & - & - & - & - & - \\
\hline 16 & $\begin{array}{l}\text { Stationary } \\
\text { Store }\end{array}$ & 1 & - & 1 & - & - & - & - & - \\
\hline 17 & $\begin{array}{l}\text { Tutorial } \\
\text { Rooms (2) }\end{array}$ & 9 & - & 2 & - & - & - & - & - \\
\hline 18 & $\begin{array}{l}\text { Girls Comm. } \\
\text { Room }\end{array}$ & 2 & - & 2 & - & - & - & - & - \\
\hline 19 & $\begin{array}{l}\text { Boys Comm. } \\
\text { Room }\end{array}$ & 2 & - & 1 & - & - & - & - & - \\
\hline 20 & $\begin{array}{l}\text { Ladies } \\
\text { Washroom }\end{array}$ & - & - & 3 & - & - & - & - & - \\
\hline 21 & $\begin{array}{l}\text { Gents } \\
\text { Washroom }\end{array}$ & - & - & 2 & - & - & - & - & - \\
\hline 22 & Corridor & - & 14 & - & - & - & - & 7 & 1 \\
\hline \multicolumn{2}{|c|}{ Total Equipment's } & 163 & $\begin{array}{c}13 \\
0\end{array}$ & 38 & 6 & 163 & 4 & 12 & 1 \\
\hline
\end{tabular}




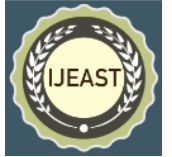

\begin{tabular}{|c|c|c|c|c|c|c|c|c|}
\hline $\begin{array}{r}\text { Rating of } \\
\text { Equipment (W) }\end{array}$ & 53 & 15 & 40 & 760 & 120 & $\begin{array}{c}153 \\
0\end{array}$ & 60 & $\begin{array}{l}15 \\
00\end{array}$ \\
\hline $\begin{array}{r}\text { Total Connected } \\
\text { load (W) }\end{array}$ & $\begin{array}{c}863 \\
9\end{array}$ & $\begin{array}{l}19 \\
50\end{array}$ & $\begin{array}{c}152 \\
0\end{array}$ & $\begin{array}{c}456 \\
0\end{array}$ & $\begin{array}{c}195 \\
60\end{array}$ & $\begin{array}{c}612 \\
0\end{array}$ & $\begin{array}{c}72 \\
0\end{array}$ & $\begin{array}{l}15 \\
00\end{array}$ \\
\hline $\begin{array}{c}\text { Energy } \\
\text { Consumption in } \\
\text { Kwh. }(8 H r / d a y)= \\
\text { (Power rating X } \\
\text { Operating } \\
\text { Hours. }) / 1000\end{array}$ & $\begin{array}{r}69 . \\
11\end{array}$ & $\begin{array}{c}15 . \\
6\end{array}$ & $\begin{array}{l}12 . \\
16\end{array}$ & $\begin{array}{l}36 . \\
48\end{array}$ & $\begin{array}{c}156 \\
.5\end{array}$ & $\begin{array}{l}48 . \\
96\end{array}$ & $\begin{array}{c}5 . \\
76\end{array}$ & 12 \\
\hline
\end{tabular}
consumption of equipment's per day. From above table the total consumption of electrical energy in institute per day is 365.55 units approximately and above calculations are done by considering standard power consumption of equipment's per Hour. Also assumed that above equipment's are on for eight hours as college has eight working hours. By observation of table-1 we can say that the maximum energy consumption in the institute per day is due to computers i.e. 156.48 units. And after that due to fans i.e. 69.1 units. In this way we identified the maximum power consumption equipment's by the walk through audit. In addition to that we observed that the institute infrastructure is constructed by considering the maximum energy conservation. Also energy efficient devices like LED Lamps, electronic regulators for fan, Latest technology computers are used for energy saving and by default it reduces the cost of energy.

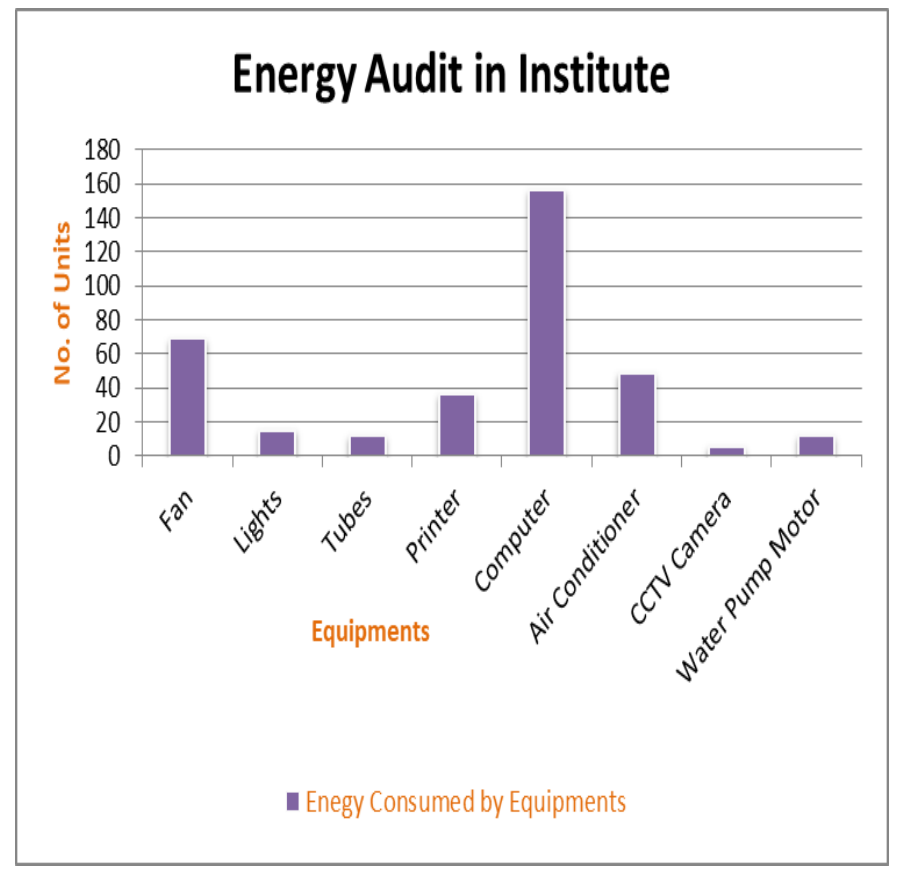

Figure 3. Energy Consumption by equipment's

\section{RECOMMENDATIONS}

We have given suggestions for reduction of power consumption in computers and fans as well as in other equipment's used in institute. Following were the recommendations given:-

a) APFC (Automatic Power Factor Correction) Panel can be installed for power factor improvement. It provides consistently high power factor under fluctuating loads, Eliminates power factor penalty. It has Lower energy consumption by reducing losses. It continuously sense and monitor the load as well as automatically switch on/off relevant capacitors steps for consistent power factor. Because of these advantages automatic power factor correction can be installed at institute.

b) Solar panel can be installed for the lighting loads.

Renewable energy sources like solar panel can be installed for lighting loads as well as for any other light load equipment's.

c) Water level indicator \& automatic control for water pump.

Water level indicator system should be implemented for water tanks to avoid wastage of water and electricity.

d) Replacement of old monitors in the computer lab by LED monitors.

e) Motion sensor / motion detectors can be installed at washrooms/corridors.

f) Replacements of lighting load by another energy efficient lamp. e.g. incandescent lamps, fluorescent lamps can be replaced by LED Lamps.

g) It is also suggested that mostly during day time natural light shall be used and only additional light requirement shall be met with electricity to conserve and save energy.

h) Display energy saving awareness Banner in each department lab, classrooms, offices, library, Seminar hall etc.

i) Avoid unnecessary use of electricity by switching off the load immediately. Also make sure that all the loads are switched off before leaving the campus area (except certain loads).

By implementing above recommendations $20 \%$ to $40 \%$ energy can be conserved.

\section{CONCLUSION}

Natural resources on earth are limited and consuming very sharply. It can be saved by employing energy efficiency and it is very necessary to prevent depletion of natural resources. In this paper we presented the purpose of energy audit in educational institute and analysed the amount of wattage consumed by different devices. Energy audit is an effective tool to identify the problems and opportunities in energy conservation. Various energy conservation techniques are used in the equipment's like transformer, motor, lighting schemes, transmission lines...etc. By replacing the conventional tube lights, fans and ACs with energy saving 


\section{International Journal of Engineering Applied Sciences and Technology, 2020 \\ Vol. 4, Issue 12, ISSN No. 2455-2143, Pages 135-139 \\ Published Online April 2020 in IJEAST (http://www.ijeast.com)}

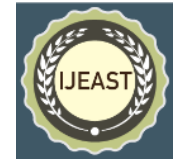

LED's, Energy efficient fans and energy saving ACs, reduces the energy Consumption drastically.

A simple change in system can conserve energy to a greater extent. By using Energy Efficient Devices we can save and reduce shortage of Power and can reduce power inflation. The research on the appliances has the potential to save not only energy, but also, to provide the institution with net economic benefits. In development process to strive with increasing energy demands, conservation and energy efficiency measures are two parallel paths.

\section{ACKNOWLEDGEMENTS}

This research was supported by our institute R.C. Patel Polytechnic Shirpur and our principal sir Prof. N.G.Haswani sir motivated and guided for this research. We are thankful to principal sir, prof. N.S.Borse, prof. G.D.Khadsane and other our colleague who are directly and indirectly supported for this research.

\section{About authors:-}

[1]. Prof. V.P.Mahajan:- he obtained his B.E. Degree in Electrical Engineering in 2013 and he has done his post-graduation in Electrical power system from NMU in the year 2016. He is working as a HOD in electrical engineering department. His research interest accumulates in the area of renewable energy resources.

[2]. Prof. Ms. H.A.Badgujar:- She obtained her B.E. Degree in Electrical Engineering in 2013 and she has done her post-graduation in Electrical power system from NMU in the year 2016. She is working as a Lecturer in electrical engineering department. Her research interest accumulates in the area of power system as well as in energy conservation and audit.

\section{REFERENCES}

[1] "Energy management and Audit" Bureau of Energy Efficiency pp.57-81

[2] M. Arumuga Babu, "ENERGY AUDIT AT TEJAA SHAKTHI INSTITUTE OF TECHNOLOGY FOR WOMEN" IJCIET Volume 8, Issue 8, August 2017, pp. 1654-1661, Article ID: IJCIET_08_08_180

[3] Dr. P. S. Aithal, P. Sridhar Acharya "TECHNIQUES FOR ELECTRIC ENERGY AUDITING IN EDUCATION SYSTEM" IJMIE, Volume 5, Issue 7, ISSN: 2249-0558.
[4] Dr. Jaganathan S2 “ Electrical Energy Auditing Of Educational Institution" IJTET VOLUME 14 ISSUE 1 - JUNE 2016 - ISSN: 2349 - 9303

[5] Gousia Sultana1, Harsha.H.U2, “ Electrical Energy Audit a Case Study" e-ISSN: 2278-1676,p-ISSN: 2320-3331, Volume 10, Issue 3 Ver. III (May Jun. 2015), PP 01-06 (IOSR-JEEE),

[6] Dr.P.V.V Rama Rao1, S.Veerababu2, K.Omkar3 "Reducing Electricity Consumption in Educational Institute: A Case Study" Vol. 5, Special Issue 8, November 2016, IJAREEIE, ISSN (Online): 2278 $-8875$

[7] Kolhe Rangnath K, "Energy audit a case study of K. J. Somaiya College of Arts, Commerce and Science, Kopargaon, MS, India, Int. IntRes. J. of Science \& Engineering, 2018; Special Issue A4:2126 ISSN: 2322-0015

[8] Adjei-Saforo Kwafo Edmund1, Adam Misbawu2, Ntiamoah-Sarpong Kwadwo3, Emmanuel O. Addo4,Su Hongsheng5 "A RESEARCH ON ELECTRICAL ENERGY AUDIT IN AN EDUCATIONAL INSTITUTION -A CASE STUDY" IJRET EISSN: 2319-1163 | pISSN: 2321-7308

[9] Nitin Kumar\& Jitender Singh (2017). "ENERGY AUDIT OF A COLLEGE CAMPUS", International Journal of Advances in Engineering \& Scientific Research, Volume 4,(Issue 5, JullAug-2017), pp 19-25. ISSN: 2349 -3607 (Online), ISSN: $2349-4824$ (Print),

[10] Harishkumar Agarwal, Smart Grid Initiative in India and Supremes'Experience in the Electrical India, Vol 53, No.9 September 2013, page 78.

[11]Zhang Jian, Zhang Yuchen, Chen Song, Gong Suzhou; "How to Reduce Energy Consumption by Energy Audits and Energy Management" Issue Date: July31 2011- Aug.2011 on page(s): 1 - 5 Date of Current Version: 12 September 2011.

[12]M. Arumuga Babu, S. Janarthanan, R.Keerrthimano and A. Bhuvanesh, Energy Audit At Tejaa Shakthi Institute of Technology For Women. International Journal of Civil Engineering and Technology, 8(8), 2017, pp. 1654-1661. http://www.iaeme.com/IJCIET/issues.asp?JType=I JCIET \&VType $=8 \&$ IType $=8$

[13] D. P. Kothari and I. J. Nagrath, "Power System Engineering”, Tata McGraw Hill, 2010. 